\title{
HIGHLIGHTS OF MINUTES
}

\section{Information Science and Automation Division Board of Directors Meeting}

1973 Annual Conference

Las Vegas, Nevada

\section{Monday, June 25, 1973}

The meeting was called to order by President Ralph Shoffner at 8:25 a.m. Those present were: BOARD-Ralph Shoffner, Paul J. Fasana, Susan K. Martin, Donald P. Hammer, and Berniece Coulter, Secretary, ISAD. GUESTS-Frederick Kilgour, James Dolby, Stephen Salmon, James Rizzolo, LaVahn Overmyer, Douglas Ferguson, and Brett Butler.

MINUTES OF MIDWINTER MEETING. There was a request that the minutes of the Board meetings at Midwinter (January 1973-Washington, D.C.) be further edited-deleting and clarifying for publication.

Mrs. Susan Martin, editor of JOLA, informed those present that the deadline for submission of copy for the March 1973 issue is the middle of July. President Shoffner suggested a separate meeting be held during conference to revise the Midwinter Minutes.

COOPERATION WITH ASIS/SIGLAN. Douglas Ferguson, representing the American Society for Information Science Special Interest Group on Library Automation \& Networks (ASIS/SIGLAN), presented a proposal for the Board's consideration that ISAD cooperate with ASIS/SIGLAN in the areas of publications, programs, and research proposals. The aims of such cooperation would be to reach people (for membership) and to save money. Mr. Ferguson was interested in the Board's response on this matter. Mrs. Martin stated that cooperation in the publications area might be relatively easy for ASIS, but for ALA it might be another matter. Mr. Ferguson felt that implementation would be the problem. He would like to focus on "specific purpose projects" functions-sharing of budget and membership.

Mr. Fasana suggested that the three chairmen of the ISAD ad hoc committees (Research Topics, Seminar and Institute Topics, and Objectives) meet with Mr. Ferguson, and that Charles Husbands, ISAD's representative to ASIS, be included.

President Shoffner named Jim Dolby, Don Bosseau, and Douglas Fer- 
guson to set up a time and place to meet with those ASIS/SIGLAN Board members present at the conference to discuss ISAD and ASIS/SIGLAN cooperation.

REPORT OF JOLA EDITOR. Mrs. Martin informed the Board of the status of JOLA. The June 1972 issue had been mailed, the September 1972 issue would be mailed in two weeks (about the middle of July), and the December 1972 issue was in the galley stage and should be mailed within six weeks. The Post Office has been told that the mailing of the JOLA issues would be caught up by the end of the calendar year. The JOLA Technical Communications has completed publication of the 1972 issues and is ready to be incorporated into JOLA. She suggested that the Board reconsider incorporating JOLA/TC into the journal since $T C$ would become neither timely nor a newsletter. The decision to incorporate originally had had been voted by the Board as a result of ALA Publishing Board's request that all Divisions cut their budget item for publications by 10 percent. The 1973/74 budget was set up for a combined journal. Mrs. Martin asked for the Board's opinion.

President Shoffner asked if it would be possible to return to a monthly publication as soon as cost allowed. Mrs. Martin replied that a reduction in the JOLA budget would have to be made to allow for monthly publication since $T C$ was now incorporated into JOLA's budget. The question was referred to the ISAD Editorial Board.

INFORMATION SCIENCE ABSTRACTS. Ben Ami Lipetz is interested in sponsorship and cooperation in relation to ISA. Several associations are now sponsors. To become a sponsor the association makes an initial financial commitment and then gains advisory board capacity. ISAD at one time had a subscription drive for fifty new ISA subscriptions from ISAD members, which was not fulfilled.

MOTION by Paul Fasana that some attempt be made to evaluate ISA and make recommendations to the Board whether ISAD should consider promoting subscriptions to ISA. SECONDED by Susan Martin. CARRIED.

REPORT OF THE COMMITTEE ON OBJECTIVES. Mr. Stephen Salmon, chairman, reported that his Committee on Objectives would meet that morning at 10:00 a.m. and they had not yet discussed the draft report. $\mathrm{He}$ had talked with the members of the committee by telephone, however.

Mr. Richard Angell had written to President Shoffner; the main point of his letter was that ISAD not accept the recommendations of the media group that ISAD incorporate them into the division. He argued that ALA organization does not provide for types of materials, although it does provide for types of libraries and types of activities. He also felt that there was not a broad enough area of mutual concern, and that COO should deal with this matter. Mr. Salmon pointed out two matters: (1) 
when the full Objectives Committee met with representatives of the Information Technology Discussion Group, there did seem to be a community of effort-the "chemistry" seemed to be there, and it did seem to work well, and (2) it was expressed that "media" has been around ALA for years, even decades, and may continue without a "home" while the best answer is still being determined. Mr. Salmon suggested that ISAD could attempt a solution at this time.

Mr. Shoffner mentioned that one of his particular concerns was that the Objectives Committee very explicitly review and then express its opinion on the relation of the Technology Group to ALA's Audiovisual Committee.

Mr. Salmon stated the committee's feelings were that ISAD objectives should be changed to include media in its scope. He asked whether the Information Technology Discussion Group should continue as a discussion group or become a committee, round table, or section. President Shoffner said he had put "Proposed Audiovisual Committee" on the agenda to determine whether or not there were strong objections to the Information Technology Discussion Group being housed in ISAD as a committee. If not, the Objectives Committee could be charged to come back to the Board with recommendations as to the form of the group.

Mr. Salmon stated, however, that the Objectives Committee was not an organization committee and the form of the group was not its concern. The establishment of a committee was provided for in the Division Bylaws. Mr. Fasana thought ISAD's objectives were broad enough as stated in the Bylaws, Article II, Section 1, the Object of the Division: particularly the words "and related technological developments." Mr. Salmon said the committee felt that media should be specifically provided for in the ISAD objectives statement rather than leaving it open to be read into the present statement.

He mentioned that historically the "founding fathers" of ISAD had merely called the name of the division: "Library Automation" but that the "Information Science" had been put in by COO to please the Reference Services Division who were interested in that area. To place the matter before COO could take six years, Mr. Fasana stated. Mr. Salmon felt, however, that it may be the time to call COO's attention to this Discussion Group so that eventually they might eliminate the nineteen or so AV committees which have no formal connection with ALA's Audiovisual Committee.

Mr. Kilgour wanted to know how the Board felt about a name change of the Division and Mr. Shoffner suggested he see Steve Salmon and Larry Auld about his suggestions.

REPORT OF RESEARCH TOPICS AD HOC COMMITTEE. Mr. James L. Dolby, chairman, expressed the feelings of his committee that the present research need lay in the area of improvement of library op- 
erations and suggested concentrating on planning and evaluating existing and proposed methods rather than on system "breakthroughs." A tremendous amount of data has been accumulated by presently operating automated systems. This data should now be put to use in research studies.

First, Acquisitions-No library is comprehensive, not even the Library of Congress. Data should be collected that should enable the library to know the ratio of use to collectivity, e.g. lists of high-use books; funneling all acquisitions through a single source to reduce duplicate buying; the possible merging of data bases (upon which circulation data can shed some light); and setting up methods by which libraries can interchange data so that comparative analyses can be made.

Second, Cataloging-Mr. Dolby made several recommendations: (1) Develop measures of cost effectiveness of various access systems. He stressed a need to provide more access to library collections, looking into the means of expanding from two or three subject headings per book in a cataloging system to forty or fifty. We need to know what people are trying to do in libraries by systematic collection of information about their activities. (2) Enumerate various types of information requests made by users. Included in this would be the collection of data on in-library use. (3) Determine needs in terms of coordinated planning, cooperation, and hardware and software transferability which should be confronted before the fact, rather than after, as more and more regional operations take shape. (4) Develop the problem-solving and idea-producing capabilities of library staffs to a maximum. (5) Develop a continuing education program for librarians covering ISAD-related topics. (6) Establish a curriculum committee to deal with problems in schools of librarianship and to make information science a teachable subject.

CONFERENCE PLANNING COMMITTEE REPORT. Chairman Brett Butler had two statements to make regarding future programs: (1) The theme of an institute program which had been postponed would be carried over to the 1974 New York Annual Conference: "Library Automation in the National Libraries," enlarged to include other national libraries; (2) the 1975 San Francisco meeting would be on "Information Science and Library Automation" and focus on the things Dolby mentioned in his Research Topics Ad Hoc Committee Report. He further stated he would like to see more co-sponsored programs.

\section{Wednesday, June 27, 1973}

President Ralph Shoffner opened the Board Meeting at 10:10 a.m. The following were in attendance: BOARD-Ralph Shoffner, Donald Hammer, Paul Fasana, Susan Martin, and Berniece Coulter, Secretary, ISAD. GUESTS-Stephen Salmon, James Rizzolo, Douglas Ferguson, Brett Butler, David Waite, Velma Veneziano, Pearce Grove, Ronald Miller, Frederick Kilgour, and Lawrence W. S. Auld.

President Shoffner pronounced a quorum present. 
SEMINAR AND INSTITUTE TOPICS. Chairman Ron Miller said the committee had reviewed the literature and felt there was value in regard to continuing education programs. He said they had received summaries and statistics on previous seminars and felt the institutes should be continued.

CONFERENCE PLANNING COMMITTEE REPORT. Brett Butler, chairman, summarized the seminars held during the year. The microforms seminar in Detroit was not held as a separate seminar but incorporated into sessions of the National Microform Association's Annual Meeting. Two other seminars were not held as planned but postponed. Surplus monies in the Preconference fund were to be used for publishing of the proceedings of the Preconference. Tapes had been professionally made of these proceedings.

The 1975 meetings were being planned now with the goal of cooperating with ASIS. The program in New York on National Libraries which was cancelled last Midwinter (1973-Washington, D.C.) was being considered with the scope to be increased to include other national libraries-France, Great Britain, etc. The program could require more time than the normal time slots. Maryann Duggan was preparing a goals document to be distributed to each participating library. Mr. Butler continued with his report saying that Maryann Duggan would plan and coordinate the Networks Seminar for the spring. The focus would be on the proposed theme-“Advertising Library Automation-How to Share Your Efforts."

The general feeling is that ISAD should also do something with other associations in state library operations and library schools.

Mr. Fasana stated that some feedback on the Las Vegas Preconference had been related in such questions as "Why was the registration fee for preconference so expensive this year?" Mr. Butler reported that a reduction in the price of the proceedings was offered to registrants. ISAD would have to subsidize ALA Publishing Services for the discount offered these registrants because ALA cannot sell at different prices to the membership. Mr. Miller stated that his committee felt that a good deal of the work now done by volunteers should be done by a staff member and those costs be included in the registration fees. This approach should be used for future seminars. Mr. Fasana said that some divisions list the analysis or a breakdown of costs on their advertising or program for preconferences.

Apparently, President Shoffner said, the price was reasonable, judging from the response. Mr. Butler said another objection was the conflict with ACRL's preconference on networks. Had we had knowledge of their preconference previously, the two could have been coordinated. Mr. Shoffner said that in a large conference conflicts were to be expected. Mrs. Veneziano felt there were few people in attendance at the networks preconference who, had it not been held, would have attended ISAD's.

PRESIDENT GIVEN AUTHORITY TO APPOINT COMMITTEE 
MEMBERS WITHOUT INDIVIDUAL APPROVAL. Mr. Kilgour asked that the Board give him the authority to appoint committee members without approval of each individual as the ISAD Bylaws stated. He asked for blanket approval. This was previously given to Mr. Shoffner. Mr. Kilgour asked that the Board invoke Section $2 \mathrm{~B}$ of the Bylaws and provide that the appointments last until the end of the president's term. Mr. Fasana suggested that a sense of "yes" be given.

REPORT OF MARBI COMMITTEE. Mrs. Veneziano, the chairman, suggested the acronym "MARBI" (Machine-Readable Bibliographic Information) be used for convenience in remembering the lengthy title of the committee. The committee was still concerned with trying to define its role and the mechanism to implement the role.

One important consideration of the committee was to serve as a link between the members of ALA and the Library of Congress in order to avoid the repetition of the problem which arose regarding ISBD and MARC records. Henriette Avram had prepared a position paper on this committee's relationship to any impending content changes to MARC records. These would not be changes required as a result of changes in cataloging rules, over which LC has no say, but rather changes in the needs of the library community.

The paper was not intended to set forth a permanent operation, but to propose guidelines. It outlined what would happen at the point where some possibility for change was discovered, and how LC and the committee would communicate. It did not, of course, detail the committee's communication with division members and the relationship of the committee to the MARC Users Discussion Group. The committee concluded that it should communicate at least with the MARC subscribers, and that James Rizzolo, chairman of the MARC Users Discussion Group, would assume the responsibility of circulating information on impending changes to the MARC subscribers and MARC users and get the information back to the committee which would determine if there was a consensus and in its best judgment give a reply back to LC.

A second activity of the committee would be to reach interested people through some means as JOLA TC or LRTS. The voluminous amount of papers should not be distributed generally as they become obsolete quickly, but a center is needed for storing these papers and the fact that they exist should be circulated to the library field in general. Copies could be made available for a price to those interested. Mrs. Veneziano hoped this could be worked out with someone at ALA Headquarters.

Another area-that of nonbibliographic data, e.g., uniform library codes, dealer codes, etc.-is of interest to the committee. Mrs. Veneziano's personal opinion was that though the function statement of the committee indicates responsibility for bibliographic information only, the committee should also be involved with anything which impacts the use of that bibliographic data. She expressed hesitancy to have many other committees 
working in this area as too much time is devoted to getting feedback from other committees before a decision can be made.

The committee would like to propose adoption of a mechanism whereby it can set up a subcommittee, task force, or working group with a limited life-span which would study and react to very specific technical proposals and working papers, etc. which are developing informally at a national and international level. These subgroups must be very responsive so that the committee will not be placed in a position where it cannot take action readily.

Also there must be a flexible mechanism for establishing subcommittees. RTSD has strong feelings on setting up such a group without approval by the division. She did not think, however, there was any objection to creating task forces and felt that it was the only way to obtain expert comment on some of these materials.

The feeling of the committee was that Henriette Avram's position paper should be accepted with minor provisos: the implementation (Section 1-B) and the time frame allowed for reporting back to LC. Henriette Avram is to go back to LC and check these modifications. If they meet LC's approval, the committee will accept the position paper.

The Character Set Subcommittee, consisting of Charles Payne, David Weisbrod, and Michael Malinconico, will study the latest draft working papers and comment to Mrs. Avram who is on the Task Force.

Mr. Fasana said the committee had power to set up subcommittees because of the board's previous approval on this; in addition, the function statement gives the committee the right to set up a task force.

President Shoffner pointed out that the results of deliberations require a joint submission to all three boards. Mr. Hammer volunteered help in any coordination which might be needed.

Comments regarding the distribution of the opinion survey that Mrs. Avram's report calls for was that it should not be general but that it be noted (perhaps in JOLA TC) that the survey is available.

Mr. Shoffner suggested that the board accept John Kountz's statement regarding the establishment of a committee on nonbibliographical data and reconsider the matter again at Midwinter. John Linford suggested that it would be best to expand the charge to the committee to include the nonbibliographical area. Paul Fasana stated that the committee's function statement now is so worded that it can include noncataloging data. The sense of the board was agreement that the authority already existed.

TELECOMMUNICATIONS COMMITTEE REPORT. The new chairman, David Waite, reported that the committee first discussed the committee's focus, as it was the desire of the board, as he understood it, to make some changes in this committee. In the past the activities of the committee were basically in cable TV. The present members were not too interested in making that their prime target, but instead the electronic communications of bibliographic data. They are not going to just look at hot is- 
sues but are currently proceeding in the area of telecommunications information, at the same time keeping their eyes open for important developments in the technological field under the broad base of telecommunications.

The two main focal points of the committee would be education and standards. In education the committee would try to communicate with decision makers as related to aspects of communications to be investigated and then overflow to the general library community.

Mrs. Martin asked if there might not be a problem with the committee's taking on this role since seminars, institutes, etc., were the function of the Conference Planning Committee. The planning for such seminars, etc., Mr. Butler said, on a six or nine month basis did not work adequately. There was no objection to the Telecommunications Committee functioning in this area,

Mr. Kilgour remarked that AT\&T and other phone companies, as well as FCC, had a great deal going on with impact on telecommunications and Butler said, on a six or nine month basis did not work adequately. There was no objection to the Telecommunications Committee functioning in this with networks presently and he felt that ALA should present a position to FCC. The committee should therefore inform itself extensively as to what is going on so that if it appears some action by ALA was needed, we would be prepared.

COMMITTEE ON OBJECTIVES REPORT. Chairman Stephen Salmon summarized the discussion by the Objectives Committee of the three issues raised at the first session of the ISAD Board meeting regarding the Information Technology Discussion Group: (1) How such a group should fit into the organizational structure of ISAD. The committee sensed a media committee was not an answer but felt a discussion group was appropriate. The media group should be continued even if transformed into a committee. (2) The restatement of the objectives and activities of the division to include the media group. Consideration was given to Paul Fasana's words that "related technology" in the ISAD Bylaws' Objectives Statement included educational technology already. But the committee agreed with the board that a change in the language would help clarify and Mr. Kilgour had some recommendations in rewording the Objectives Statement to solve the problem. (3) Terminology for the name of the division and the journal. They finally identified three possible name changes for the division: (a) Information Science and Library Automation, (b) Information Science and Educational Technology, and (c) Information Science and Technology. The final decision was that the present name of the division, "Information Science and Automation," was the best.

The committee also thought the draft report should specifically include another objective, i.e., to offer expertise in this area to others in ALA and other professional organizations like ARL.

Mr. Salmon listed the additions and changes made and included in the final draft of the committee's report. 
MOTION Paul Fasana moved that the ISAD Board accept and adopt the report of the Objectives Committee. SECONDED by Susan K. Martin. CARRIED.

Mrs. Martin remarked that the Information Technology Discussion Group was already within ISAD. Mr. Shoffner explained that the Board had accepted the group only for one year and during that year ISAD intended to determine whether this activity was within ISAD's scope.

Mrs. Martin asked, if ISAD considers educational technology and audiovisual concerns to be within its scope, what the relationship would be with the other audiovisual committees in ALA and also what COO's role would be? The Board was not asserting what is out of scope with any other parts of ALA, Mr. Shoffner answered, only what was within ISAD's scope. President Shoffner thanked Chairman Salmon for his report and the committee for its work in carrying out the original charge as given and meeting the time schedule. He then declared the committee disbanded.

There was some discussion on coordinating with other AV committees in ALA and what aspect of AV, ISAD would be concerned with. Mr. Kilgour suggested that the Information Technology Discussion Group should pursue its own goals and not concern itself with the coordination of all ALA AV groups. Such coordination he felt was impossible. Whether a number of committees or subcommittees in the discussion group could be formed was also discussed. Mr. Shoffner stated that these should be "units" of the discussion group, not "committees." He further said he was reluctant to establish committees and would do so only after a group of people committed to doing a job showed, over some continuing period of time, productive activity on a number of different tasks that relate to each other.

REPORT OF EDITORIAL BOARD. Mrs. Martin said that at the Monday ISAD Board meeting she had talked of retaining JOLA TC as a separate publication, but the final feeling of the Editorial Board was negative. The thought was to create a separate section within JOLA but with a different format, as the green sheets are inserted in the Library Association Record ("Liaison").

Don Bosseau, editor of JOLA TC, remarked that the Editorial Board had provided insight into another need which was for truly technical communications, e.g., a short summary which would show up later in a longer, detailed article. The Editorial Board felt that TC should be made into something that has more impact than news releases.

ISAD/LED EDUCATION COMMITTEE REPORT. A written report was submitted by the committee. (See Exhibit A.)

COLA REPORT. The membership of the Discussion Group had increased to 145. Chairman Don Bosseau, who has held that position since the incorporation of the group within ISAD, said ballots would be sent out shortly for the election of a new chairman. 
Mr. Bosseau also asked about control of membership in the group and stated that ALA's guidelines indicate one person per institution as a maximum membership. The Board corrected this idea by saying that this limitation was not ALA's but the old COLA limitation. There is no limit on membership by ALA.

Mr. Butler asked that the planning of COLA, MARC, and Information Technology Discussion Groups' meetings be coordinated.

Mrs. Martin said that David Weisbrod had suggested that there be a COLA meeting at ASIS and that would be part of the cooperation between ASIS and ISAD in the program area.

MARC USERS DISCUSSION GROUP. Mr. James Rizzolo told of his intent to make a survey by breaking up the mailing lists he had into three groups: (1) MARC subscribers, (2) those interested in using MARC, and (3) an informational group.

Mr. Kilgour thought the group was called "MARC Subscribers" not "MARC Users." Mr. Shoffner said the name had always been MARC Users. Originally there had been the intent to set up a "MARC Subscribers" group but Mr. Culbertson had said that it would not fit into either ISAD or ALA's structure. They then settled on MARC Users Discussion Group.

It was stated that both MARC and COLA Discussion Groups should be in the program section of the ALA Conference Program book. It was pointed out that program time can be requested by committee or discussion group chairmen.

INFORMATION TECHNOLOGY DISCUSSION GROUP. Mr. Shoffner requested $\mathrm{Mr}$. Donald Hammer to inform the ISAD Information Technology Discussion Group that the board would not establish an AV committee, but intended to continue with the Information Technology Discussion Group in response to their memo of March 2, 1973 requesting an AV committee within ISAD.

REPORT TO ALA PLANNING COMMITTEE. Mr. Shoffner also requested Mr. Hammer to forward the Objectives Committee report on the long range plans of ISAD to the ALA Planning Committee as a means to meet their request. (This report had been deferred from Midwinter so that the final report of the Objectives Committee could first be heard.)

RTSD COMPUTER FILING COMMITTEE. Mr. Fasana said he was asked by the RTSD Board why ISAD had refused their request to appoint an ISAD member to the RTSD Computer Filing Committee. Mr. Hammer said he would see that a committee member was appointed.

Mr. Shoffner expressed appreciation to the board and turned over the gavel to President Fred Kilgour. The meeting was adjourned at 12:00 noon. 
EXHIBIT A

JUNE 25, 1973

\section{MINUTES OF THE 1973 ANNUAL ISAD/LED MEETING}

The 1973 annual meeting of ISAD/LED convened June 25 at Caesar's Palace, Atrium I, Las Vegas. Present were members Jim Liesener, Ann Painter and Elaine Svenonius; and visitors Martha West (California State University, San Jose), Barbara Fleming (University of Nevada, Reno) and Philip Heer (University of Denver); in attendance were Pauline Atherton and Charles Davis.

Discussion centered on two topics: the DISC questions as commented upon by Library School faculties and the future course of DISC.

The general and specific comments on the DISC questions given by library school faculties are given on the attached sheets. These sheets include, in addition to responses reported at ALA, responses which arrived belatedly throughout the summer. General criticisms are primarily of two types: the questions are either too broad or they are outside the domain of information science. It was felt that had the use to which the questions are to be put-viz., to develop modules, not to examine graduating students-been clearer, the charge "too broad" would not have resulted. As to what is to be included in the domain of information science, this was precisely the point of the exercise of generating questions and comments limiting or extending the domain of information science, should be accorded consideration.

At the June 25 meeting, the individual questions were discussed generally in light of comments received.

Following the discussion, participants at the meeting expressed informally and with varying degrees of determination interest in developing modules around certain of the questions.

The meeting ended with a discussion of the future of DISC. A technical session is being planned by the ES SIG at Los Angeles in October: Program Modules for Developing Curricula in Information Science; the plan for module development will be advertised and some demonstration modules shown with a view to drawing up module specifications. Also contemplated is a program by ISAD/LED in January at Midwinter ALA.-Elaine Svenonius, August 15, 1973. 